\title{
Effect of Process Parameters \& Tool Geometries on Properties of Friction Stir Spot Welds: A Review
}

\author{
Sachin Jambhale $^{1, *}$, Sudhir Kumar ${ }^{2}$, Sanjeev Kumar ${ }^{3}$ \\ ${ }^{1}$ MGMCoET, Noida (U.P), India \\ ${ }^{2}$ NIET, Greater Noida (U.P), India \\ ${ }^{3}$ YMCA University of Science and Technology, India
}

Copyright $(2015$ Horizon Research Publishing All rights reserved.

\begin{abstract}
Friction stir spot welding is the energy efficiency, environment friendly and relatively new low energy technology adopted from Friction stir welding (FSW) with many potential applications in joining light alloys in the automotive industry. In 2001, Friction stir spot welding (FSSW) was developed in the automotive industry to substitute resistance spot welding for aluminum sheets. FSSW process has some advantages such as ease of joining materials, low distortion, excellent mechanical properties, low power consumption, low cost and more economical than RSW. The strength of welds is critical when applying FSSW to load bearing components. This strength is affected mainly by process parameters and tool geometry. Tool geometry, such as shoulder diameter and shape, pin shape, length, diameter and feature is a key parameter to affect heat generation and material flow. The objective of this paper is to review open literature sources to assess the current state-of-the-art developments in Friction Stir Spot Welding, effect of various welding variables like tool rotation, transverse speed, dwell time, tool tilt, plunge depth and tool design on mechanical properties in the welding of aluminium alloys or various dissimilar alloys. However the Literature review indicates that there is need to identify the effect of different process parameters on Mechanical properties in FSSW.
\end{abstract}

Keywords FSW (Friction Stir Welding), FSSW (Friction Stir spot Welding), Dwell Time, Plunge Depth, Tool Geometry

\section{Introduction}

The future direction of automotive manufacturing will be towards the greater use of

light alloys. This increase is predominantly due to demands placed on manufacturers to reduce fuel consumption, reduce exhaust emissions and meet recyclability targets. It is also desirable in the current climate to decrease the energy requirements of manufacturing processes. Aluminium alloys have attracted attention of many researchers, engineers and designers as promising material for automotive industry and thus more energy efficient methods for joining aluminium alloys. Friction Stir Spot Welding (FSSW) is a relatively new joining process, which has many potential applications in the automotive industry and aerospace applications.

There are clear drivers in the automotive sector towards lower fuel consumption through the introduction of more weight efficient designs involving the substitution of Aluminium and Magnesium alloys for steel and dissimilar material combinations in hybrid structures. New joining techniques are required for these materials and in particular for dissimilar combinations. It is also desirable to reduce the energy requirements of manufacturing processes used in the automotive industry. Friction stir spot welding (FSSW) is emerging as a very attractive joining method for aluminium vehicle bodies, with potential also for high strength steel. As a joining process it has several advantages over other point joining methods.

Other than the linear process, another major variation of the process is Friction Stir Spot Welding (FSSW). The FSSW process involves only the plunge and retraction of the FSW tool as shown in the diagram in Figure 1. The traverse part of the process is eliminated. The FSSW process mimics the Resistance Spot Welding (RSW) process and can be used in place of RSW, riveting, clinching or any other single point joining processes in many applications.

One of the most significant factors that influence the joint strength of a friction stir spot weld is the tool geometry. The tool geometry used in FSSW has been traditionally derived from friction stir linear welding and there has not been much focus on developing tool geometries specifically for FSSW.

Due to recent trends in these industries of using strong and lightweight alloys to meet more stringent safety and fuel economy requirements, more exotic and complex alloys, which are difficult to join, using conventional methods, are being used. It is proposed that by utilizing the solid-state benefits of FSSW, these materials can be joined faster and cheaper while still maintaining the required joint strength. 
Table 1. Key benefits of FSSW.

\begin{tabular}{|c|c|c|}
\hline Metallurgical benefits & Environmental benefits & Energy benefits \\
\hline
\end{tabular}

\section{FSSW Process}

As an iteration of the Friction Stir Welding (FSSW) process, the Friction Stir Spot Welding (FSW) process offers many of the benefits associated with FSW. In FSW, a non-consumable tool is used to create a weld of appreciable length, while the FSSW process creates a weld in a distinct location or "spot" using a similar tool. Generally speaking, the FSSW process is comprised of a plunge sequence, a stirring sequence, and a retract sequence. The sum of these sequences constitutes the total cycle time of the welding process. For many years now, FSSW has been investigated and developed for use in a number of applications in the automotive and aerospace industries.

The FSSW process consists of three phases; plunging, stirring and retracting as shown in Fig. 1. The process starts with spinning the tool with a high rotational speed. Then the tool is forced into the weld spot until the shoulder of the tool enters the surface of the upper work piece. The plunge movement of the tool causes material to expel as shown in Fig. 1a and $\mathrm{b}$. When the tool reaches the predetermined depth, the plunge motion ends and the stirring phase starts. In this phase, the tool rotates in the work pieces without plunging [6]. Frictional heat is generated in the plunging and the stirring phase and, thus, the material adjacent to the tool is heated and softened. The softened upper and lower work piece materials mix together in the stirring phase. The shoulder of the tool creates a compression stress on the softened material. A solid-state joint is formed in the stirring phase. When a predetermined bonding is obtained, the process stops and the tool is retracted from the work pieces. The resulting weld has a characteristic keyhole in the middle of the joint as shown in Fig. 1c. The tool geometry and welding parameters (tool rotational speed, tool plunge depth and dwell time) effect heat production, joint formation and strength of welds.
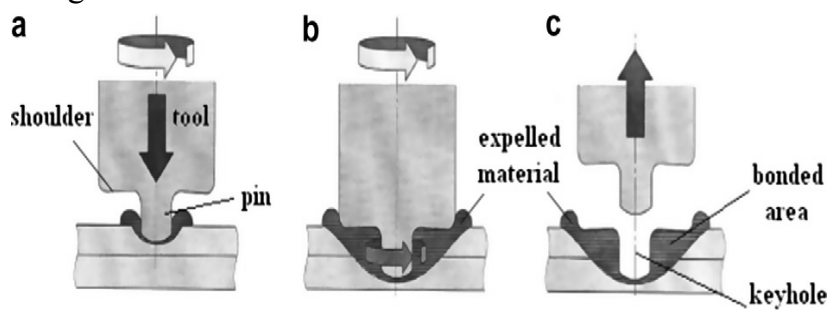

Figure 1. Three phases of friction stir spot welding process, (a) plunging, (b) stirring and (c) retracting
A schematic illustration of the friction stir spot welding process is shown in Figure.1. In FSSW a high speed rotating tool with a probe/ pin is plunged into the upper sheet of a lap joint and the down force on the rotating tool is maintained for an appropriate time to generate sufficient frictional heat and deformation to form a solid-state bond between the surfaces of the upper and lower sheets.

There are three main modes of the FSSW process: traditional, swept, and refill. The traditional method is very similar to the plunge sequence of a friction stir weld. A single piece non-consumable tool is plunged into the material, held for a period of time, and then retracted leaving an exit hole. Swept FSSW moves the tool in a circular path incorporating $\mathrm{X}$ and $\mathrm{Y}$ motion once the final plunge depth is reached. Refill FSSW utilizes a tool consisting of a pin.

\section{Welding Process Parameters in FSSW}

\subsection{Rotation Speed}

In FSW of steels it is generally recommended to keep the rotation speed low in order to preserve the original properties of the steel. A rotation speed lower than $500 \mathrm{rpm}$ is recommended for FSW of low carbon steel. These recommendations apply for linear FSW, where the traversing movement of the tool contributes to the stirring of the material around the tool. These recommendations are not applicable for FSSW. Only very little is reported in the literature about varying the rotation speed in FSSW. The mechanical properties of the joints welded at the higher rotational speed are obviously lower than that at the lower rotational speed [10]. However, the studies in the literature are not very extensive and the effect of the rotation speed on the microstructure evolution in the weld is not fully understood.

Table 2. Welding process parameters.

\begin{tabular}{|c|c|c|c|}
\hline Welding & Tool & External factors & $\begin{array}{c}\text { Pre-or post } \\
\text { treatment }\end{array}$ \\
\hline Rotation speed, & $\begin{array}{c}\text { Material, } \\
\text { Design, } \\
\text { Dwell time, }\end{array}$ & $\begin{array}{c}\text { Shielding gas, } \\
\text { Tool }\end{array}$ & $\begin{array}{c}\text { Preheating, } \\
\text { Post-heat } \\
\text { Plunge rate, }\end{array}$ \\
Down Force & $\begin{array}{c}\text { cooling, Pin } \\
\text { Height }\end{array}$ & piece & $\begin{array}{c}\text { Post-surface } \\
\text { treatment }\end{array}$ \\
& & & \\
\hline
\end{tabular}




\subsection{Dwell Time}

The dwell time corresponds to the time during which the probe stays in rotation at its bottom location before extracting. The dwell time is the most dominant welding parameter for weld strength followed by the rotational speed $[7,8]$. A longer dwell time is expected to induce a larger heat generation in the weld because there is more time for the tool to generate heat in the weld. In the literature, there are only a few studies, which describe the effect of dwell time on FSSW of steel. At first, it has been found that when increasing the dwell time, there seems to be an improvement of the tensile shear strength. Indeed, a long dwell time induced a larger welded area, but simultaneously a long dwell time induced a higher quantity of intermetallic compounds.

\subsection{Plunge Rate}

The plunge rate has not received much attention in the literature. During plunging of the tool into the work piece, the tool and work piece are heated up. A higher plunge rate will give a higher heating rate and the microstructure is more rapidly affected in the beginning of the weld cycle. A fast plunge rate will also induce more wear on the tool because the material is less softened in the initial plunging stage. The plunge rate was found to have greater influence on tensile shear fracture load.

\subsection{Pin Height}

The FSSW joints that were obtained with higher pin heights resulted in a higher tensile shear strength. These results can be explained by the larger volume of bonded materials as the pin height increases. Increasing the pin height has a positive effect on the tensile shear strength.

\subsection{Tool Shoulder Diameter}

Increasing tool shoulder diameter from for a fixed welding parameter caused increasing the mechanical properties (hardness and shear force) of the spot welded joints [2].

\subsection{Tool}

Material selection and design profoundly affect the performance of tools, weld quality and cost. There are high demands on the tool used for joining of steel. The major reason for this is the higher melting temperature and yield strength of steel compared to aluminum. Many materials have been investigated as a candidate for the tool. Basically there are two types of tools; metal-based and ceramic tools. The metal-based tools include W, Re, W-Re, WC-Co and Mo-based materials, which all have been investigated as tool materials for FSW and

FSSW of various steel grades. It is recognized that wear occurs in most of the studies with the metal-based tools. The ceramic tool materials include Si3N4, Tic/TiN and polycrystalline boron nitride (PCBN) and the most common problem with these tools is fracture of the tool due to the brittle nature of the ceramics. According to the recommendations in the literature, the most promising tool material is PCBN.

There is need for concerted research efforts towards development of cost effective durable tools for application of FSSW of different alloys.

\section{Applications}

Friction Stir Spot Welding is derived from the FSW process and with the elimination of the keyhole could have a major effect on the automotive industry. The original application for friction stir welding was the welding of long lengths of material for the aerospace, shipbuilding and railway industries.

With the new technique used by Mazda, a spot-joining technique, the rear doors and the bonnet of the $2004 \mathrm{RX}-8$ are FSSW.

\section{Current Status and Future aspects}

Unlike Linear FSW, which is predominantly used for Butt welding, most of the spot friction stir welding is done in Lap configuration. Spot FSW, a key contender to compete with existing Spot welding techniques such as RSW, SPR \& TOX has evolved strongly since the beginning of this decade when Mazda introduced it for the first time on a production line [11]. The usual cycle time for a typical spot welds in on the order of a few seconds. It is during this short interval that the tool has to plunge into the work piece, stir and metallurgically bond the material and retract. So far, research has been done on optimizing key welding parameters such as tool rotation rate, plunge speed, target depth and dwell time to better understand the influence of each parameter on the weld quality (which is typically mechanical strength of the joint)

Several important key issues \& problems associated with FSSW.

The success of FSSW in Aluminium alloy body structures has led to tremendous interests in applying the technology to weld advanced high strength steels. However, past research and development on linear friction stir welding have shown that steels are much more difficult to friction stir weld than Al alloys. The technical difficulties stem from the very fundamental aspect of the FSW process - compared to aluminum alloys, FSW of AHSS must operate at much higher temperatures and it requires much higher mechanical loading for plunging and stirring.

Some problems associated with FSSW are as follows.

1. Formation of void in the middle of the weld zone after welding.

2. Very small contact zone

3. Ineffective removal of oxides and other 
contamination from the weld interface (as there is no relative motion between them)

4. Poor mixing of materials (sheets) used for lap joint welding (as there is no relative motion between them)

These technical difficulties are also expected for FSSW. The high-volume, high-speed, and cost-conscious requirements of auto-body assembly lines make the development of FSSW even more challenging.

\section{Conclusions}

Significant research and developments in the field of FSSW process has occurred around the world. With its ability to join lightweight, high strength aluminum alloys, this process has established itself as a viable joining option for the automotive and aerospace industries. FSSW process can provide a technical and economical edge over traditional welding processes.

1. FSSW is a robust process, with capability to generate welds of good strength over a wide range of welding parameters.

2. In most of the research papers, three levels of welding parameters were selected

3. Dwell time, Tool plunge depth and Tool rotational speed were effective on joint strength.

4. Dwell time must not exceed a certain value, otherwise it can weaken the weld.

5. Effect of tool pin height on the tensile shear strength is greater than dwell time and tool rotation.

6. The quality of FSSW is highly dependent on tool design. All of these strength results are tool design dependent as well as alloy and thickness dependent.

7. The large number of parameters affecting the mechanical properties of welded joints requires planning characterization tests; this reduces time and cost of experiments.

8. The improvement in the weld strength for welding parameters is about $40 \%$

9. There are significant advantages of FSSW over more established joining methods like less power consumption, produces an excellent joint, is extremely fast when compared with mechanical methods and produces a homogenous joint suitable for recycling.

\section{Acknowledgements}

The authors are grateful to the Department of Mechanical Engineering, MGM's College of Engineering \& Technology \& JSSATE, Noida for extending the resources to carry out this work. The authors also wish to record their sincere thanks to the Dr Sunil Wagh, Director, MGMCoET, Noida for his support to carry out this work. 


\section{Appendix}

1. Case studies: Effect of various process parameters on FSSW.

\begin{tabular}{|c|c|c|c|c|}
\hline $\mathrm{Sr}$ & $\begin{array}{l}\text { Journal Name, } \\
\text { Year, Volume }\end{array}$ & $\begin{array}{c}\text { Process parameters \& } \\
\text { ranges }\end{array}$ & To find & Results \\
\hline 1 & $\begin{array}{l}\text { Materials and } \\
\text { Design } 32 \\
(2011) 4074- \\
4079\end{array}$ & $\begin{array}{l}\text { Tool rotation } \\
\text { speed(rpm) } 700-1100 \\
\text { Dwell time(s) } 20-60 \\
\text { Tool plunge } \\
\text { depth(mm) } 5.7-6.7\end{array}$ & $\begin{array}{l}\text { To investigate friction stir spot } \\
\text { welding parameter effects on the } \\
\text { weld strength. } \\
\text { To find the significant } \\
\text { parameters and the optimal } \\
\text { combination level of welding } \\
\text { parameters. }\end{array}$ & $\begin{array}{l}\text { 1. The dwell time was the most dominant welding parameter } \\
\text { for weld strength followed by the tool rotation speed. } \\
\text { 2. The optimum welding parameters for the weld strength are } \\
\text { the tool rotation speed of } 700 \mathrm{rpm} \text {, the dwell time of } 60 \mathrm{~s} \text { and } \\
\text { the tool plunge depth of } 6.2 \mathrm{~mm} \text {. } \\
\text { 3. The improvement in the weld strength from the initial } \\
\text { welding parameters to the optimal welding parameters was } \\
\text { about } 40 \% \text {. }\end{array}$ \\
\hline 3 & $\begin{array}{l}\text { Soldagem \& } \\
\text { Inspeção, } \\
(2012) \text { Vol.17, } \\
\text { N.1,026-031. }\end{array}$ & $\begin{array}{l}\text { Rotational speed } \\
\text { (rpm) 2000-3000 } \\
\text { Plunge depth } \\
\text { (mm) } 2.3-3.0 \\
\text { Dwell time (s) } \\
0-3\end{array}$ & $\begin{array}{l}\text { The effect of friction spot } \\
\text { welding parameters on lap shear } \\
\text { strength of AZ31 alloy by } \\
\text { Taguchi method. }\end{array}$ & $\begin{array}{l}\text { Tool plunge depth was found to have the greatest influence on } \\
\text { both mean and } \mathrm{S} / \mathrm{N} \text { ratio (around } 60 \% \text { of contribution), } \\
\text { followed by rotational speed and dwell time. } \\
\text { The optimum combination suggested by Taguchi method was } \\
\text { found to be } 2500 \mathrm{rpm} \text { of rotational speed, } 3.0 \mathrm{~mm} \text { of plunge } \\
\text { depth and } 1.5 \text { seconds of dwell time. }\end{array}$ \\
\hline 4 & $\begin{array}{l}\text { Materials and } \\
\text { Design } 31 \\
(2010) 3023- \\
3028\end{array}$ & $\begin{array}{l}\text { Tool rotating speed, } \\
1000 \text { to } 2000 \mathrm{rpm} \text {. and } \\
\text { welding feed rate } \\
\text { The downward and } \\
\text { upward welding speed } \\
\text { ranged from } 16 \text { to } 31.5 \\
\mathrm{~mm} / \mathrm{min}\end{array}$ & $\begin{array}{l}\text { To determine the optimal } \\
\text { parameters making it possible to } \\
\text { have a good joint of welding for } \\
\text { an alloy of } 6060-\mathrm{T} 5 \text { type. }\end{array}$ & $\begin{array}{l}\text { The tensile tests made it possible to establish the sample with } \\
\text { (1000 rpm and } 16 \mathrm{~mm} / \mathrm{min} \text { ) has a good quality of welding, (5 } \\
\mathrm{kN} \text { to } 16 \mathrm{~mm} / \mathrm{min} \text { and } 1000 \mathrm{rpm} \text { ) compared to ( } 1.98 \mathrm{kN} \text { for } 25 \\
\qquad \mathrm{~mm} / \mathrm{min} \text { and } 2000 \mathrm{rpm}) \text {. } \\
\text { The quality of the welded joint is all the more important as the } \\
\text { tool rotating is decreased and that of welding is increased. }\end{array}$ \\
\hline 5 & $\begin{array}{c}\text { Journal of } \\
\text { Engineering }(20 \\
11) \\
\text { Volume } 17 \\
\text { Number } 6\end{array}$ & $\begin{array}{l}\text { Shoulder diameter } \\
\text { D (mm) } 10-19 \\
\text { Preheat dwell time } \\
\text { (sec) } 20 \mathrm{sec} \\
\text { Plunging time } \\
\text { (sec) } 60 \mathrm{sec}\end{array}$ & $\begin{array}{c}\text { To understand the effect of tool } \\
\text { shoulder diameter on the } \\
\text { mechanical properties of the } \\
\text { joint. } \\
\text { For this purpose four welding } \\
\text { tools diameter }(10,13,16 \text { and } \\
\text { 19) mm at constant preheating } \\
\text { time and plunging time were } \\
\text { used to carry out welding } \\
\text { process. }\end{array}$ & $\begin{array}{l}\text { As shoulder diameters increase from } 10 \text { to } 19 \mathrm{~mm} \text { for a given } \\
\text { preheating and plunging time causing increase in shear force } \\
\text { (weld force). The highest shear weld failure force } 2200 \mathrm{~N} \text { was } \\
\text { obtained at tool shoulder diameter } 19 \mathrm{~mm} \text {. } \\
\text { The weld joint fabricate with tool of } 19 \mathrm{~mm} \text { diameter showed } \\
\text { better mechanical properties than the others. }\end{array}$ \\
\hline 6 & $\begin{array}{l}\text { Materials and } \\
\text { Design } 32 \\
(2011) 4461- \\
4470\end{array}$ & $\begin{array}{l}\text { Rotational speed } 1541 \\
\text { and } 2256 \mathrm{rpm}, \mathrm{dwell} \\
\text { time of } 5 \mathrm{~s} \text { and } 15 \mathrm{~s} \text {. }\end{array}$ & $\begin{array}{l}\text { To find the effect of tool } \\
\text { rotational speed and dwell time } \\
\text { on microstructure and } \\
\text { mechanical properties of friction } \\
\text { stir spot welded } 5052 \\
\text { aluminum alloy } \\
\end{array}$ & $\begin{array}{l}\text { The joints strength decreases with increasing tool rotational } \\
\text { speed, while it's almost independent of the given tool dwell } \\
\text { times. At the rotational speed of } 1541 \mathrm{rpm} \text {, the tensile/shear } \\
\text { strength and cross-tension strength reaches the maximum of } \\
2847.7 \mathrm{~N} \text { and } 902.1 \mathrm{~N} \text { corresponding to the dwell time of } 5 \mathrm{~s} \\
\text { and } 15 \mathrm{~s} \text {. }\end{array}$ \\
\hline 8 & $\begin{array}{l}\text { Materials and } \\
\text { Design 35 } \\
\text { (2012) 113-119 }\end{array}$ & $\begin{array}{l}\text { Dwell time } 50 \text { and } \\
150 \mathrm{~s} \text {, } \\
\text { Tool plunge depth } 5.7 \\
\text { and } 6.7 \mathrm{~mm} \\
\text { Tool rotation } \\
\text { speed } 700-1100 \mathrm{rpm}\end{array}$ & $\begin{array}{l}\text { To estimate the contribution of } \\
\text { individual welding parameters to } \\
\text { the strength of the weld joint. } \\
\text { To prepare Response table for } \\
\text { weld strength. }\end{array}$ & $\begin{array}{l}\text { The dwell time, the tool plunge depth and the tool rotational } \\
\text { speed were effective on joint strength of polypropylene FSSW. } \\
\text { The dwell time was the most dominant welding parameter and } \\
\text { the tool rotational speed was the least important welding } \\
\text { parameter. } \\
\text { The optimum welding parameters for the weld strength are } \\
\text { roughly the dwell time of } 100 \mathrm{~s} \text {, the tool plunge depth of } 5.7 \\
\mathrm{~mm} \text { and the tool rotation speed of } 900 \mathrm{rpm} \text {. }\end{array}$ \\
\hline 9 & $\begin{array}{l}\text { International } \\
\text { Journal of } \\
\text { Machine Tools } \\
\& \text { Manufacture } \\
47 \text { (2007) 2230- } \\
\text { 2236 } \\
\end{array}$ & $\begin{array}{l}\text { probe length }(2.4-3.7 \\
\mathrm{mm}) \text {, tool rotational } \\
\text { speed }(2000-3000 \mathrm{rpm}) \\
\text { and tool holding } \\
\text { time }(0.2-3.0 \mathrm{Secs})\end{array}$ & $\begin{array}{l}\text { To find the effect of probe length } \\
\text { on static strength and the fracture } \\
\text { mechanisms in friction stir spot } \\
\text { welds of } 6061 \text { aluminium alloy } \\
\text { sheets. }\end{array}$ & $\begin{array}{l}\text { The tensile shear strength increased with increasing probe } \\
\text { length, while the cross-tension strength was not affected } \\
\text { significantly by probe length. } \\
\text { With increasing tool rotational speed and tool holding time, } \\
\text { the tensile shear strength increased, while the cross-tension } \\
\text { strength decreased. }\end{array}$ \\
\hline 10 & $\begin{array}{l}\text { Materials and } \\
\text { Design } 37 \\
\text { (2012) 384-392 }\end{array}$ & $\begin{array}{l}\text { Applied Load } \\
(\mathrm{kg})(1000-2000) \\
\text { Rotation speed } \\
(\mathrm{rpm})(600-1000) \\
\text { Dwell time }(\mathrm{s})(2 \mathrm{~s})\end{array}$ & $\begin{array}{l}\text { To obtain sound joints with } \\
\text { smooth surfaces and without } \\
\text { any internal welding defects \& } \\
\text { with the successful application } \\
\text { of the flat spot friction stir } \\
\text { welding technology to } \\
\text { aluminum alloys, }\end{array}$ & $\begin{array}{l}\text { The flat spot FSW technique was applied to mild steel sheets } \\
\text { in this study, which has a much higher melting point than that } \\
\text { of aluminum alloys. } \\
\text { It was revealed that sound welds with high mechanical } \\
\text { properties can be obtained and the technique show high } \\
\text { feasibility for the joining of mild steel. }\end{array}$ \\
\hline
\end{tabular}




\section{REFERENCES}

[1] Badarinarayan H, Yang Q, Zhu S, Effect of tool geometry on static strength of friction stir spot-welded aluminum alloy. International Journal of Machine Tools and Manufacture, Vol.49, No.2, 142-148, 2009.

[2] Dr.Ayad, M.Takhakh., Samer, J. AL-Jodi., Mohamed A. Al-khateeb, Effect of Tool Shoulder diameter on the Mechanical properties of 1200 Aluminium Friction Stir Spot Welding, Journal of Engineering,Vol. 17,No.6, 1517-1523, 2011.

[3] A. Gerlich, M. Yamamoto \& T.Shibayanagi, T.H. North, Selection of welding parameter during friction stir spot welding. SAE International Journal of Materials and Manufacturing, Vol. 1, 1-8, 2009.

[4] M. I. Khan, M L Kuntz, P. Su, A. Gerlich, T. North, and Y. Zhou, Resistance and friction stir spot welding of DP600: a comparative study. Science and Technology of Welding \& Joining, Vol.12, No.2, 175-182, 2007.

[5] Leonardo. Contri, Campanelli, Uceu. Fuad, Hasan. Suhuddin, Jorge. Fernandez, dos. Santos, Parameters Optimization for Friction Spot Welding of AZ31 Magnesium Alloy by Taguchi
Method. Soldagem \& Inspeção, Vol.17, No.1, 026-031, (2012).

[6] Mohamed. Merzoug, Mohamed. Mazari, Lahcene. Berrahal, Abdellatif. Imad, Parametric studies of the process of friction spot stir welding of aluminium 6060-T5 alloys, Material and Design,Vol.31,No.6,3023-3028,2010.

[7] Mustafa Kemal Bilici, Application of Taguchi approach to optimize friction stir spot welding parameters of polypropylene, Materials and Design , Vol.35, 113-119, 2012.

[8] Mustafa Kemal Bilici, Ahmet Irfan Yukler, Memduh Kurtulmus, The optimization of welding parameters for friction stir spot welding of high density polyethylene sheets, Materials and Design, Vol.32, 4074-4079, 2011.

[9] C. B.Smith, J. F.Hinrichs, P. C. Ruehl, Friction Stir and Friction Stir Spot Welding. Lean, Mean, and Green, Sheet Metal Welding Conference XI, Vol.2,No.5,11-14, 2004.

[10] Zhang Zhao-hua, Yang Xin-qi, Zhang Jia-long, Zhou Guang, XU Xiao-dong, Zou Bin-lian,Effect of welding parameters on microstructure and mechanical properties of friction stir spot welded 5052 aluminum alloy, Materials and Design. Vol.32, 4461- 4470, 2011.

[11] Rajiv.S.Mishra, Murray W Mahoney, Friction Stir Welding and Processing, ASM International, USA, 2007 